\title{
Instrumen Pengukur Creativity And Innovation Skills Siswa Sekolah Menengah di
} Era Revolusi Industri 4.0

\author{
Mohammad Mukhlis ${ }^{1}$, Mohammad Tohir ${ }^{2}$ \\ ${ }^{1}$ Dosen Program Studi Tadris Matematika, IAIN Jember \\ ${ }^{2}$ Dosen Program Studi Tadris Matematika, Universitas Ibrahimy Situbondo \\ e-mail:mmukhlis166@gmail.com
}

\begin{abstract}
Abstrak
Penelitian ini bertujua untuk memberi gambaran dalam mengembangkan instrument sebagai bentuk pengukur Creativity And Innovation Skillssiswa pada mata pelajaran matematika. Berpikir kreatif dan inivatif merupakan suatu prosesmenemukan suatu solusi baru yang sebelumnya bekum ada, untuk menyelesaikan suatu masalah matematika secara mudah dan fleksibel. Adapun langkah-langkah dalam mengembangkan instrumen adalah menyusun spesifikasi, menulis, menelaah, uijicoba, menganalisis, memperbaiki, dan merancang instrumen.Spesifikasi intrumen menunjukkan keseluruhan karakteristik yang dimiliki instrument.Sedangkan dalam menyusun spesifikasi instrumen, terdapat 4 hal yang harus diperhatikan, yaitu: menentukan tujuan pengukuran instrumen, menyusun kisi-kisi instrumen, bentuk dan format instrumen, dan panjang instrumen. Penulisan soal merupakan penjabaran dari berbagai indikator yang menjadi acuan pedoman pertanyaan-pertanyan yang sesuai dengan karakteristik pada kisi-kisi yang telah disusun.Kegiatan analisis dilakukan terhadap masing-masing butir soal yang telah diberi bobot skor.Memperbaiki tes merupakan upaya perbaikan-perbaikan terhadap butir soal yang kurang sesuai dengan yang diharapkan.Setelah semua buitr soal disusun, danalisis dan diperbaiki, selanjutnya adalah merancang butir-butir soal tersebut menjadi instrument.
\end{abstract}

Kata Kunci: Instrumen, Creativity and Innovation Mathematic Skills, Revolusi Industri 4.0

\section{PENDAHULUAN}

Ilmu pengetahuan dan teknologi selalu berkembang sesuai dengan zamannya masingmasing, sehingga kualitas pendidikan dari zaman ke zaman selalu meningkat lebih tinggi dari pada sebelumnya. Mulai dari Era Revolusi 1.0, 2.0, 3.0 hingga saat ini berada pada Era Revolusi Industri 4.0 dengan percepatan ilmu pengetahuan yang sangat pesat.Pada Era Revolusi Industri 4.0 ini, pendidikan menjadi sangat penting untuk mengembangkan peserta didik memiliki kemampuan kreatif dan inovatif, memanfaatkan teknologi dan informasi, dan berkomunikasi serta bekerjasama.Pembelajaran matematika pada era ini memiliki visi dan misi untuk membentuk pola berpikir seseorang menjadi mampu berpikir kritis, kreatif, komunikatif, dan kolaboratif."Mathematics is the bedrock of any contemporary order of science" (Thalhahet al., 2019). Hal ini selaras dengan beberapa hasil penelitian yang dilakukan oleh National Council of Teacher of Mathematics (NCTM) terdapat lima kemampuan matematis dasar yang seharusnya dimiliki siswa yakni (1)mathematical communication; (2) mathematical reasoning, (3) mathematical problem-solving, (4) mathematical connection, dan (5) mathematical representation (Ferrini-Mundy \& Martin, 2000). Oleh karena itu, kamampuan matematis seseorang akan berdampak kuat terhadap kemampuan berpikirnya, apabila kemampuan berpikir tersebut selalu diasah dan dikembangkan secara kontinu.

Kemampuan berpikir seseorang merupakan suatu proses mental dalam mengembangkan gagasan atau ide dari berbagai informasi yang didapat, sehingga menghasilkan suatu produk tertentu. Seseorang dapat dikatakan mempunyai kemampuan berpikir yang baik dan kuat, apabila mampu melakukan berbagai cara untuk 
menghasilkan suatu ide, mengkolaborasikan, mengevaluasi, menganalisa dan membuat sesuatu hal yang baru. Adapun kemampuan berpikir seseorang terbagi menjadi dua kelompok tingkatan, yaitu berpikir tingkat rendah dan berpikir tingkat tinggi. Kemampuan berpikir tingkat tinggi merupakan salah satu pengukur kualitas pendidikan. Sebagai seorang peserta didik yang nantinya akan menjadi agen perubahan harus mampu menunjukkan jati dirinya dengan cara yang intelektual, bermoral, dan elegan. Umtuk mencapai hal tersebut, guru harus mampu merubah mindsetnya dari penyampai ilmu pengetahuan menjadi fasilitator untuk mendapatkan ilmu pengetahuan tersebut. Berkenaan dengan ilmu pengetahuan, maka mata pelajaran yang menjadi ratunya ilmu pengetahuan adalah matematika. Karena matematika mempunyai peranan yang sangat penting dalam perkembangan ilmu pengetahuan dan teknologi yang sangat cepat ini.Disamping itu, tujuan utama diberikannya pelajaran matematika mulai dari tingkat dasar sampai ke perguruan tinggi di Era Revolusi Industri 4.0 adalah mengembangkan kemampuan berpikir tingkat tinggi (HOTS) yang dimiliki oleh peserta didik. HOTS adalah proses berpikir secara kompleks dalam mengurai materi, mengkonstruk representasi, menganalisis, mengevaluasi, dan membuat kesimpulan dengan operasi mental.Karakteristik HOTS menurut Conklin (2012) yaitu mencakup berpikir kritis, kreatif, dan pemecahan masalah.

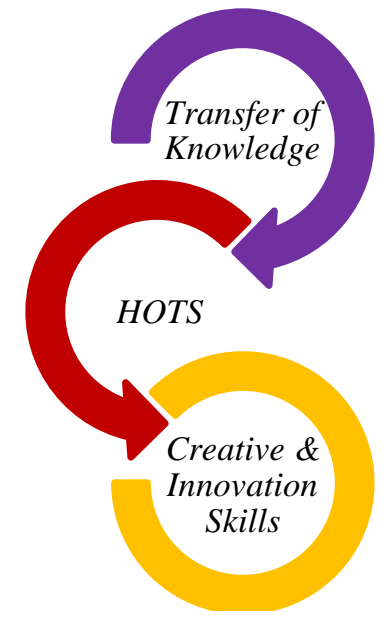

Gambar 1. Hubungan Karakteristis HOTS

Menurut Dafik(2015) ketiga tahapan keterampilan tersebut tidak mudah untuk dilaksanakan. Dibutuhkan perencanaan sistematis untuk mengaplikasikan, keterlibatan unsur penting proses pembelajaran, unsur-unsur adalah guru, siswa, dan instrument. Guru harus mampu menstimulasi kemampuan tersebut secara seimbang dalam proses pembelajaran.

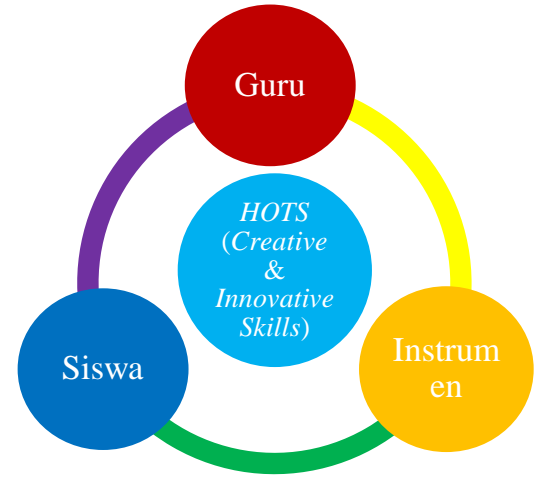

Gambar 2 Hubungan Ketiga Unsur Creative \& Innovative Mathematic Skills

Guru fokus pada materi yang akan didiskusikan dalam kelas, melalui pembelajaran HOTS yang bersumber dari kelompok diskusi siswa. Kemudian, guru menyusun instrumen penilai berdasarkan penerapan pembelajaran HOTS yang dilakukan dalam kelas. Pembelajaran HOTS merupakan pembelajaran berorientasi pada keterampilan berpikir tingkat tinggi, peran guru tidak banyak menerangkan, sebaliknya guru banyak melakukan stimulasi pertanyaan untuk mendorong memunculkanya pikiran-pikiran orsinil siswa(As'ari et al., 2017).

Oleh karena itu, pada Era Revolusi Industri 4.0 ini proses pembelajaran yang dilaksanakan di sekolah harus benar-benar diperhatikan, agar dapat menghasilkan lulusan yang kompeten. Keterampilan berpikir menurut Bloom Revisi (Sobirin et al., 2016)dibagi menjadi dua bagian, yaitu pertama keterampilan berpikir tingkatrendah (Lower Order Thinking Skills atau LOTS) yang terdiri dari tiga indikator tingkatan yakni: mengingat $(\mathrm{C} 1)$, memahami (C2), dan menerapkan (C3). Kedua merupakan keterampilanberpikir tingkat tinggi (Higher Order Thinking Skills atau HOTS) yang terdiri dari tiga indikator,yaitu: menganalisis (C4), mengevaluasi (C5), dan mencipta (C6). HOTS yang dimaksud dalam kajian ini adalah kemampuan berpikir kritis dan kreatif. (Mukhlis, Dafik, \& Hobri, 2018) mengatakan bahwa"the concept of critical thinking is one of the most significant trends in education and has a dynamic relationship in the learning process". Hal ini diperkuat pendapat mengenai beberapa karakteristik HOTS menurut Conklin (2012) yaitu karakteristik berpikir tingkat tinggi meliputi kemampuan berpikir kritis dan berpikir kreatif.

Berpikir kreatif merupakan keterbukaan dalam berpikir dan responsive. Aktivitas 
berpikir kreatif anatara lain: merancang, menyampaikan gagasan, memecahkan masalah, dan mengkreasi. Proses siswa dalam mengembangkan kemampuan berpikir kreatif merancang suatu ide untuk pemecahan masalah, menggunakan pengetahuan dari informasi untuk mengkreasi untuk menemukan solusi dengan cara baru. Pengertian berfikir kreatif sediri diungkapkan oleh Martin(Tohir, Susanto, Hobri, Suharto, \& Dafik, 2018) mengatakan bahwa "the ability of creative thinking is the ability to generate ideas or new ways to produce a product". "One of thinking abilities essential for the students to experience more meaningful learning and improve their thinking skill in solving everyday problems is creative thinking". Menurut Guilford(Azwar, 2011) berpikir kreatif adalah berpikir lintas bidang, berpikir bisosiatif, berpikir lateral, berpikir divergen. Berpikir kreatif ditandai dengan karakteristik berpikir yang fluency, flexibility, originality, elaboration, redifinition, novelty. Hal ini diperkuat oleh pendapat Munandar (Tohir et al., 2018) "suggests that creative thinking can be defined as the ability to reflect the aspects offluency, flexibility, originality, and elaboration. In creative thinking, learner will go a series ofstages, inter alia, synthesizing ideas, building ideas, planning the implementation of ideas, andapplying these ideas to produce something". Sehingga dapat diartikan bahwa kreatif adalah seseorang yang dapat menghadirkan sesuatu atau suatu ide atau gagasan tertentu yang sebelumnya belum ada untuk dipergunakan dalam memecahkan suatu masalah. Di samping itu, berpikir kreatif juga menuntut adanya pengikatan diri terhadap tugas (task commitment) yang tinggi.Artinya, kreativitas menuntut disiplin yang tinggi dan konsisten terhadap bidang tugas.Kreativitas, dapat dinilai dari ciri-ciri aptitude seperti kelancaran, fleksibilitas dan orisinalitas, maupun ciri-ciri non-aptitude, antara lain temperamen, motivasi, serta komitmen menyelesaikan tugas.Kreativitas merupakan salah satu ciri dari perilaku yang inteligen karena kreativitas juga merupakan manifestasi dari suatu proses kognitif. Meskipun demikian, hubungan antara kreativitas dan inteligensi tidak selalu menunjukkan bukti-bukti yang memuaskan.

Menurut Doppelt (2009: 57)menyampaikan pemikiran kreatif untuk siswa melalui proses desain proyek-proyek mereka membutuhkan tidak hanya mengubah metode pengajaran, tetapi juga mengadopsi baru metode penilaian dengan instrument yang tepat dan sesuai perkembangan. Hal ini dapat memberkan rangsangan kepada siswa sehingga mereka mampu mempertanyakan, menganalisis, mensintesis, memecahkan masalah, dan menciptakan ide-ide baru atau merancang dan membangun produk yang berguna atau sistem. Indicator berpikir kreatif menurut Preparing 21st Century Student sebagai berikut:

\section{a. Berpikir kreatif}

Berpikir terbuka untuk membuat ide dalam pemecahan masalah, teliti, memperbaiki, menganalisis dan mengevaluasi ide-ide, meningkatkan dan memaksimalkan.

b. Bekerja kreatif

Mengembangkan, menerapkan dan mengkomunikasikan ide-ide baru secara efektif, responsif terhadap perspektif baru dan beragam; menggabungkan masukan kelompok dan umpan balik ke dalam pekerjaan, mengadopsi ide-ide baru.

c. Membuat inovasi

Maampu mengevaluasi dan melihat segala bentuk kekurangan, menunjukkan orisinalitas ide atau temuan.

Inovasi pada dasarnya adalah suatu usaha yang gigih untuk menemukan sesuatu hal yang baru agar dapat diemplementasikan pada situasi/kondisi tertentu yang sebelumnya belum ada dan belum terpikirkan oleh orang lain.Menurut Suyatno (Syafaruddin et al., 2016) dalam melakukan inovasi pendidikandi sekolah maka diperlukan tersedianya guru-guru inovatif. Sikap kreatifguru inovatif ditandai oleh: (1) keterbukaan terhadap pengalaman baru, (2) kelenturan dalam berpikir, (3) kebebasan dalam ungkapan diri, (4) menghargai fantasi, (5) minat terhadap kegiatan kreatif, (6) kepercayaan terhadap gagasan sendiri, dan (7) kemandirian dalam memberikan pertimbangan sendiri. Hal ini, sesuai dengan pernyataan Gravemeijer \& Cobb(2006) bahwa design research bertujuan menciptakan ekologi pembelajaran inovatif guna mengembangkan teori-teori pengajaran lokal (Local Instruction Theories) dan diperkuat oleh Sunardi (2016) menyampaikan bahwa seseorang dikatakan kreatif dan inovatif, jika orang tersebut menggunakan pendekatan baru untuk mendapatkan hasil dan inovasi yang sama atau hasil dan inovasi. 
Adapun hasil penelitian yang dilakukan oleh Yudha, Dafik, \& Yuliati(2018) menunjukkan bahwa tidak ada siswa yang mencapai tingkat berpikir kreatif level 0, sehingga hal ini berarti bahwa siswa menguasai keterampilan berpikir kreatif dan inovatif dalam memecahkan masalah, terutama dalam memecahkan set dominasi. Sedangkan hasil penelitian yang didapat oleh Zubaidah(2018) menunjukkan bahwa domain utama keterampilan abad 21 yang berupa literasi digital, pemikiran yang intensif, komunikasi efektif, produktifitas tinggi dan nilai spiritual dan moral dapat tercapai melalui latihan-latihan yang berkelanjutan di dalam proses pembelajaran yang disesuaikan dengan karakteristik siswa.

Menganalisis karakteristik siswa merupakan tahap yang paling penting dalam perencanaan pembelajaran, dimana karakteristik siswa di tingkat sekolah dasar itu berbeda dengan mereka yang berada pada tingkat sekolah menengah(Alfin, 2014). Seels dan Richey(Budiningsih, 2011)mengatakan bahwa karakteristik siswa adalah bagianbagianpengalaman siswa yang berpengaruhpada keefektifan proses belajar. Sedangkan menurut Musfiqon(2012) mengatakan bahwa ada 3 hal yang perlu diperhatikan dalam memahami karakteristik siswa, yaitu: keadaan psikologis, tipe belajar, serta kemampuan awal yang dimiliki dalam proses pembelajaran.

Psikologi perkembangan

Secara umum, dari sisi psikologi perkembangan siswa (remaja) mengalami perubahan fundamental dalam aspek kognitif, emosi, sosial, dan fisik.Piaget mengemumakan bahwa pada fase tersebut mereka mulai berintegrasi dengan masyarakat dewasa dan mulai merasa setara dengan yang lebih tua dalam perspektif hak.

Gaya belajar

Gaya belajar setiap siswa penting dipahami oleh guru untuk mengetahui pengaruh pada proses pembelajaran. Cara paling efektif untuk mengetahui gaya belajar siswa biasa diamati dari kecerdasan majemuk. Menurut Gardner kecrdasan yang dimilki oleh siswa yaitu: kecerdasan logis-matematis, visual-spasial, kinestetis, linguistic, interpersonal dan intrapersonal.

Kemampuan awal

Kemampuan awal siswa merupakan gambaran kesiapan siswa dalam menerima transfer ilmu yang disampaikan oleh pendidik. Keberhasilan siswa dalam pembelajaran tergantung dari kesiapan siswa.Kesiapan siswa ada dua macam, perkembangan mental dan pengetahuan prasyarat. Siswa tidak akan memahami persamaan kuadrat apabila belum memahami persamaan linear (pengetahuan prasyarat belum ada).

Berdasarkan uraian di atas, maka instrumen dalam mengukur tingkat berpikir kreatif dan inovatif siswa merupakan suatu hal yang sangat penting. Hal ini bertujuan untuk mengukur dan memberi stimulus bagi siswa dalam memecahkan masalah, dan bagi pendidik bertujuan untuk melatih mengembangkan kemampuan dalam menysusun soal HOTS. Sehingga dikaji lebih dalam perihal bagaimana cara atau sintakmatik dalam mengukur kemampuan berpikir kreatif dan inovatif matematika siswa

Tabel 1. Indikator berpikir kreatif dan inovatif matematika

\begin{tabular}{|c|c|c|c|}
\hline HOTS & Indikator & Sub-indikator & Deskripsi \\
\hline $\begin{array}{l}\text { Berpikir kreatif } \\
\text { dan inovatif } \\
\text { matematika }\end{array}$ & Evaluasi & $\begin{array}{l}\text { - Merangkum } \\
\text { - Membuktikan kembali } \\
\text { - Menilai }\end{array}$ & $\begin{array}{l}\text { - } \text { Mampu menerapkan } \\
\text { rumus fungsi } \\
\text { - Mampu } \\
\text { mengidentifijkasi dan } \\
\text { mengklasifikasikan } \\
\text { masalah } \\
\text { - Mampu merangkum dan } \\
\text { mendeskripsikan } \\
\text { - Mampu mengeneralisasi } \\
\text { dari rumus fungsi } \\
\text { - Mampu memberikan } \\
\text { kesimpulan }\end{array}$ \\
\hline
\end{tabular}




\section{METODE}

Penelitian ini dilakukan untuk mengukur kemampuan berpikir kreatif dan inovatif matematika dengan menggunkan metode pengembangan. Prosedur pengembangan dalam mengukur kemampuan siswa mengacu pada Madapi (2012), yakni menyusun spesifikasi instrument, menulis soal instrument, menelaah soal instrument tes dan merakit soat intrumen. Batasan pengembangan intrumen pengukur kemampuan berpikir kreatif dan inovatif matematika siswa hanya menganalisis butir soal yang telah diuji coba. Berikut tahahan pengembangan yang akan dilakukan:

1. Menyusun spesifikasi instrumen soal

Pada tahapan ini, ditentukan tujuan diselenggarakannya tes. Tujuan yang ingin ditetapkan mengacu pada apa yang ingin diukur dari peserta didik. Setelah tujuan ditetapkan, dilakukan penyusunan kisi-kisi tes dan menentukan bentuk dan panjang tes.

\section{Menulis soal instrumen}

Berdasarkan kisi-kisi yang telah disusun, butir-butir soal dikembangkan sebanyak yang telah ditetapkan. Adapun banyaknya butir soal yang dibuat berjumlah 200 butir khusus pada aspek geometri dan pengukuran bangun datar.

\section{Menelaah soal instrument tes}

Pada tahapan ini, butir-butir soal yang telah dibuat ditelaah dari segi kaidah penulisan soal bentuk pilihan ganda. Butir- butir soal yang telah ditelaah dan tidak sesuai dengan kaidah, maka perlu dilakukan revisi pada butir soal tersebut. Hal ini dilakukan guna menghasilkan butir soal yang baik sebelum diujicoba. Telaah mengacu pada 16 kaidah penulisan soal yang dikembangkan oleh Depdiknas. (2000), yang terdiri atas materi, konstruksi, dan bahasa.

4. Merakit soat intrumen

\section{HASIL DAN PEMBAHASAN}

\section{A. Instrumen berpikir kreatif dan inovatif}

Menurut Azwar(2011)menyatakan bahwa para ahlipsikometri telah menetapkan kriteriabagi alat ukur, seperti instrumen, untukdinyatakan sebagai alat ukur yang baik.Kriteria tersebut antara lain adalahvalid, reliabel, standar, ekonomis danpraktis. Adapun menurutGronlund, Linn, \& Miller(2009) menyatakan bahwa karakteristik utamayang harus dimiliki oleh sebuah alatukur dapat diklasifikasikan menjadikarakter validitas, reliabilitas dantingkat kegunaannnya. Secara singkatdan jelas, dalam membuat instrumenpenelitian pengembangan. Sedangkan sintakmatik dalam merakit instrumen pengukur berpikir kreatif dan inovatifdalam penelitian ini adalah sebagai berikut:

\section{Menyusun Spesifikasi Instrumen}

Ada 4 hal yang perlu menjadi perhatian bagi pendidik dalam menyusun spesifikasi instrumen, yaitu: menentukan tujuan pengukuran instrumen, menyusun kisi-kisi instrumen, bentuk dan format instrumen, dan panjang instrumen, yaitu sebagai berikut.

\section{a. Menentukan tujuan pengukuran \\ instrumen}

Pada dasarnya tujuan instrumen dapat ditentukan sendiri oleh pembuat instrumen.Akan tetapi, pada kajian ini merupakan kajian untuk mengukur tingkat kemampuan berpikir kreatif dan inovatif siswa.

\section{b. Menyusun kisi-kisi instrumen}

Ada lima langkah dalam menyusun kisikisi instrumen, yaitu (1) menentukan definisi konseptual berdasarkan teori-teori tertentu dari berbagai sumber pustaka yang terkait, (2), mengembangkan definisi operasional, (3) menentukan aspek-aspek instrumen yang akan dikembangkan, (4) menulis indikator berdasarkan aspek-aspek isntrumen, dan (5) menentukan bentuk tes.

c. Menyusun bentuk dan format instrumen

Berbagai bentuk instrumen dapat digunakan sesuai dengan karakteristik masingmasing aspek yang dinilai. Aspek yang dinilai antara lain tes tertulis, tes lisan, penugasan, dan portofolio. Bentuk instrumen antara lain benarsalah, menjodohkan, pilihan ganda, isian/melengkapi, uraian, tanya jawab, tugas yang dilakukan secara individu maupun kelompok, dan hasil pekerjaan siswa yang diperoleh dari penugasan atau tes tertulis. Sedangkan format instrumen terdiri dari aspek yang dinilai, indikator soal, butir soal, jumlah soal pada masing-masing indikator, dan teknik penilaian atau rubrik penilaian. Berikut salah satu contoh format kisi-kisi instrumen minat dapat dilihat pada tabel 2 . 
Tabel 1.Kisi-kisi Instrumen Pengukuran Minat siswa

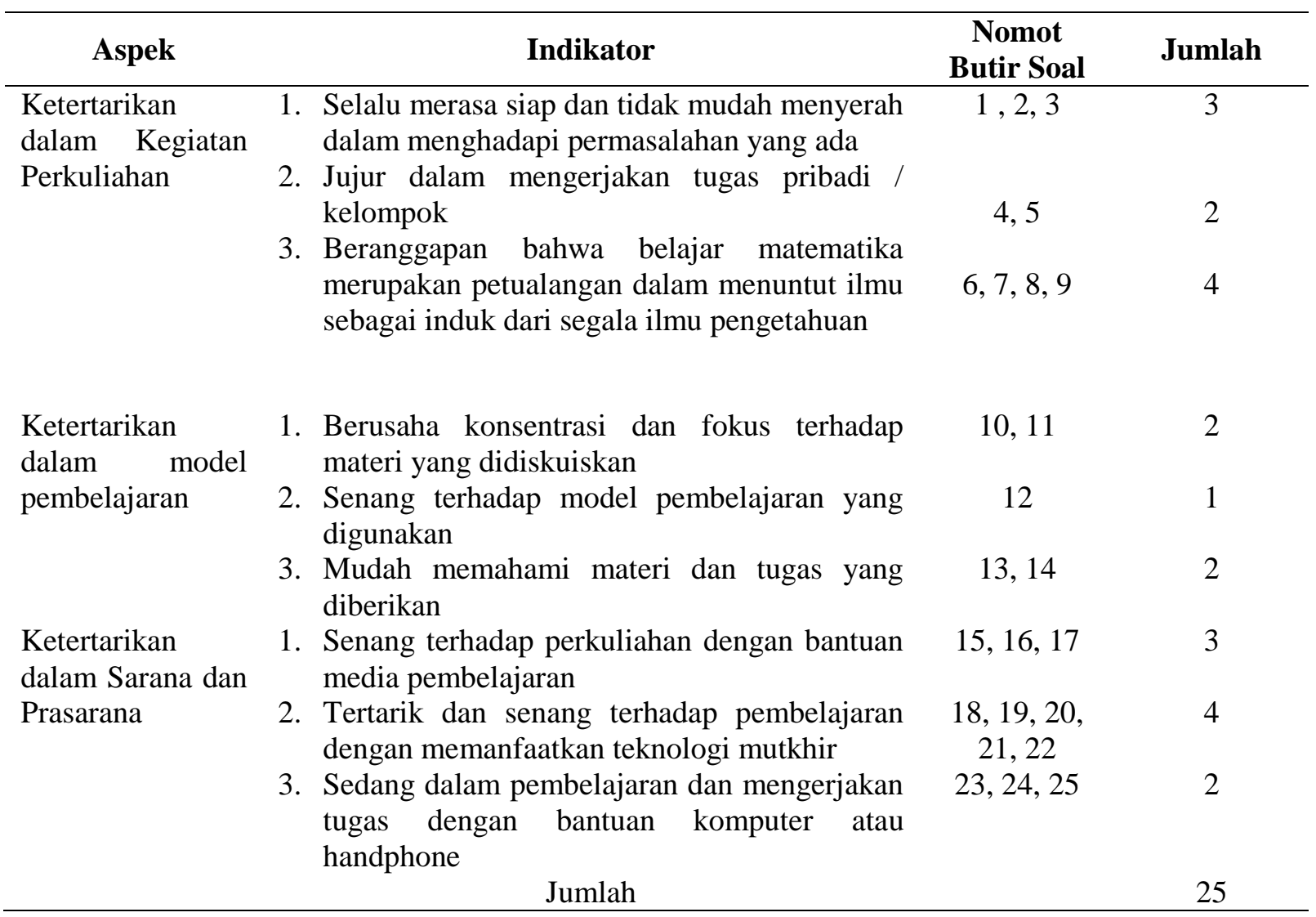

\section{d. Menentukan Panjang Instrumen Tes}

Semua butir soal yang disusun, harus memperhatikan kedalaman materi yang sudah dipelajari sesuai dengan indikator-indikator yang telah disusun dan redaksi soal yang disusun tidak melebihi setengah halaman kertas untuk satu butir soal. Menurut Safihin \& Hamdani (2019) mengatakan bahwa menentukan waktu yang disediakan berdasarkan tingkat perkembangan peserta didik dan jenjang Pendidikan, yaitu tes dikerjakan selama 2 jam pelajaran atau $2 \times 45$ menit.

2. Menulis Soal Instrumen Tes

Apabila sudah ditentukan indikator, keluasan dan kedalaman instrumen tes, maka langkah selanjutnya adalah menuliskan instrument tes.Instrumen tesini disesuaikan dengan kaidah EYD (Ejaan Yang Disempurnakan), dan hendaknya mengecek ulang setelah instrumen tes dibuat, dengan tujuan apakah tata tulis, redaksi, dan maksud kalimatnya sudah tepat. Menurut Rusilowati(2013) mengatajan bahwa hal yang perlu diingat ketika menyusun instrumen afektif adalah penentuan kalimat pernyataan. Ada dua macam pernyataan, favorable dan unfavorable. Kedua pernyataan ini berhubungan dengan penetapan skala. Skala untuk penrnyataan favorable berlawanandengan unfavorable. Jika salah dalam menentukan skala, maka kesimpulan yang dihasilkan juga akan salah.

3. Menelaah Soal Instrumen Tes

Telaah soal instrumen ini dilakukan oleh ahli/pakar pada pelajaran matematika. Tahap ini disebut proses validasi oleh ahli. Hasil dari telaah oleh validator, menunjukkan kualitas instrumen yang dibuat.Jika belum valid, maka perlu diadakan perbaiki/revisi berdasarkan pada saran-saran yang diberikan oleh validator.Setelah selesai diperbaiki, instrumen tersebut diberikan kembali kepada validator untuk dinilai masingmasing butirnya. Hal ini sesuai dengan yang disarankan oleh Usman (2017) mengatakan bahwa telaah soal ini sebaiknya dilakukan olehorang lain, bukan si pembuat soal. Seringkali kelemahan dan kekurangan, baik daritata bahasa maupun dari substansi, tidak dapat terlihat oleh pembuat soal. Akan lebihbaik jika telaah dilakukan oleh sejumlah orang yang terdiri dari para ahli yang 
secarabersama dalam tim menelaah dan atau mengoreksi soal.

4. Merakit Soal Instrumen Tes

Setelah semua butir soal yang disusun dianalisis dan diperbaiki, selanjutnya adalah merakit butir-butir soal tersebut menjadi satu kesatuan instrumen. Semua butir soal tersebut harus tersusun dengan jelas dan hati-hati untuk menjadi satu-kesatuan untuh dalam suatu tes. Kemudian yang perlu menjadi perhatian juga adalah validitas soal, urutan soal berdasarkan level kognitif, dan berdasarkan jenjang objek yang di tes. Hal ini sesuai dengan pendapat Agustika (2019) mengatakan bahwa merakit butir-butir soal yang telah memenuhi kriteria yang diharapkan menjadi satu kesatuan tes, keseluruhan butir perlu disusun menjadi soal tes yang terpadu.

\section{B. Kegiatan Pengukuran Berpikir Kreatif dan Inovatif Matematika}

Kemampuan berpikir kreatif dan inovatif siswa bisa dikembangkan, apabila kemampuan tersebut terus-menerus dilatih secara kontinu. Sehingga dalam proses pembelajaran di kelas guru sebaiknya selalu memberikan soal-soal atau latihan yang memuat soal berpikir kreatif dan inovatif. Bisa juga dilakukan ketika diadakan suatu tes/ujian guru memberikan soalsoal yang memuat soal berpikir kreatif dan inovatif, meskipun hanya beberapa butir soal. Hal tersebut sesuai dengan yang disampaikan oleh CCEA (Curriculum, Assessment andExaminations) bahwa bahwa guru dan praktisiharus memiliki beberapa panduanpraktis tentang bagaimanaketerampilan berpikir dapatditingkatkan dalam tahun pertama anakmasuk sekolah, dan bagaimana untukmenilai apakah anak-anak berpikirdengan cara yang konstruktif atautidak. Oleh karena itu, seseorang akan memilik berpikir kreatif dan inovatif, maka ia harus berani membiasakan diri berpikir kritis, karena beripikir kritis akan melatih seseorang dapat memiliki kemampuanberpikir jernih dan rasional. Berpikir kritis juga akan membuat seseorang memiliki banyak ide-ide kreatif dan inovatif.

Adapun kegiatan yang harus dilakukan oleh guruahar mengetahui tingkat kemampuan berpikir kritis siswa dapat disebut sebagai kegiatan pengukuran.Keberhasilan guru dalam melakukan uji coba kepada siswadapat diketahui melalui suatu pengukuran, seperti memberikan tes yang memuat soal berpikir kritis.Sehingga hasil pengukuran yang dilakukan oleh gutu, dapat dipercaya apabila dalam beberapa kali guru tersebut melakukan pengukuran terhadap subjek yang sama, akan diperoleh hasil yang relatif sama (reliable) juga dengan syarat instrumen yang dihunakan tetap.Selainreliabel, instrumen tes yang dijadikan sebagai alat ukur oleh gutu, harus diestimasi terlebih dahulu kevalida dari instrumen tes tersebut. Sehingga instrumen tersebut mempunyai validitas yang tinggi dan akuran apabila instrumen tersebut dijalankan sesuai dengan fungsinya. Begitu sebaliknya, apabila suatu instrumen tes menghasilkan data yang tidak relevan, maka instrumen tersebut memiliki kevalidan yang rendah. Sehingga tidak baik digunakan sebagai alat ukur berpikir jreatif dan inovatif siswa.

\section{SIMPULAN}

Pembelajaran pada Era Revolusi Undustri 4.0 adalah pembelajaran yang berorientasi pada Higher Order Thinking Skills (HOTS).Pembelajaran sangat dibutuhkan guna mengukur kesiapan dan kemampuan dalam berpikir yang lebih tinggi. Salah satu dari komponin kemampuan berpikir tingkat tinggi adalah kemampuan berpikir kreatif dan inovatif.

Adapun sintaksis dari penyusunan instrumen pengukur berpikir kreatif dan inovatif adalah menyusun spesifikasi, menulis, menelaah, menganalisis, dan merakit instrumen.Spesifikasi instrumen menunjukkan pemaparan dari tujuan tes sesuai dengan kisikisi yang berpedoman pada indicator.Penulisan soal merupakan penjabaran dari indicator yang berupa pertanyaan-pertanyaan yang sesuai dengan karakteristik.Memperbaiki tes berarti melakukan revisi terhadap soal-soal yang kurang sesuai dengan indikator. Setelah semua butir soal sudah disusun, dianalisis dan diperbaiki, selanjutkan merakit semua soal menjadi satu kesatuan yaitu instrumen pengukur.

Kajian ini diharapkan untuk dikritisi atau ditindaklanjuti guna menjadi penelitian terkait mengembangkan instrumen kemampuan berpikir kreatif dan inovatif maupun yang lain.

\section{DAFTAR PUSTAKA}

Agustika, G. N. S. (2019). Pengembangan Konstruksi dan Validasi Tes Konsep Dasar Matematika. Journal of Education Technology, 2(1), 40-44. 
Alfin, J. (2014). Analisis Karakteristik Siswa pada Tingkat Sekolah Dasar. Prosiding Halagoh Nasional \& Seminar Internasional Pendidikan Islam. Surabaya: Fakultas Tarbiyah dan Keguruan, UIN Sunan Ampel Surabaya.

As'ari, A. R., Tohir, M., Valentino, E., Imron, Z., \& Taufiq, I. (2017). Buku Guru Matematika (Revisi). Jakarta: Pusat Kurikulum dan Perbukuan, Balitbang, Kemendikbud.

Azwar, S. (2011). Reliabilitas Dan Validitas. Yogyakarta: Pustaka Pelajar. Yogyakarta: Pustaka Pelajar. Https://Doi. Org/10.22146/Bpsi, 13, 381.

Budiningsih, C. A. (2011). Karakteristik Siswa Sebagai Pijakan dalam Penelitian dan Metode Pembelajaran. Jurnal Cakrawala Pendidikan, 1(1), 160-173.

Conklin, W. (2012). Strategies for Developing Higher-Order Thinking Skills, Grades 612. Shell Education.

Dafik. (2015). Teori Graf, Aplikasi dan tumbuhkan Keterampilan Tingkat Tinggi. Jember: Universitas Jember.

Doppelt, Y. (2009). Assessing creative thinking in design-based learning. International Journal of Technology and Design Education, 19(1), 55-65.

Ferrini-Mundy, J., \& Martin, W. G. (2000). Principles and standards for school mathematics. Reston: National Council of Teachers of Mathematics (NCTM).

Gravemeijer \& Cobb. (2006). Design Research from a Learning Perpective, dalam Educational Design Research. New York: Routledge.

Gronlund, N. E., Linn, R. L., \& Miller, M. D. (2009). Measurement \& Evaluation in Teaching (Tenth Edit). New York: Macmillan Publishing Co., Inc.

Hamzah, A. (2014). Evaluasi Pembelajaran Matematika. Jakarta: PT Raja Grafindo Persada.

Mukhlis, M., Dafik, D., \& Hobri, H. (2018). Student Critical thinking in Solving Two Dimensional Armetics Problems Based on 21th Century Skills. International Journal of Advanced Engineering Research and Science, 5(4), 19-30.
Musfiqon, H. M. (2012). Pengembangan Media dan Sumber Pembelajaran. Jakarta: PT. Prestasi Pustakaraya.

Rusijono, M. (2008). Penelitian Teknologi Pembelajaran. Surabaya: Unesa University Press.

Rusilowati, A. (2013). Pengembangan Instrumen Nontes. Makalah. Seminar Nasional Evaluasi Pendidikan Di Universitas Negeri Semarang, 7-21.

Safihin, M., \& Hamdani, H. (2019). PENGEMBANGAN TES MENGGUNAKAN MODEL RASCH MATERI GAYA UNTUK SMA. Jurnal Pendidikan Dan Pembelajaran, 8(6), 111.

Sobirin, M.; Koes, S.; \& Kusairi, S. (2016). Level Keterampilan Berpikir Siswa Pada Materi Optika. Pros. Semnas Pend. IPA Pascasarjana UM, 1, 373-380.

Sunardi. (2016). Strategi Penguatan Pengembangan 4C's dalam Pembelajaran Matematika. Prosiding Seminar Nasional Pendidikan Matematika, 8-19. Malang: Universitas Negeri Malang.

Syafaruddin, S., Asrul, A., Mesiono, M., Wijaya, C., \& Usiono, U. (2016). Inovasi Pendidikan: Suatu Analisis Terhadap Kebijakan Baru Pendidikan. Medan: Perdana Publishing.

Thalhah, S. Z., Tohir, M., Nguyen, P. T., Shankar, K., \& Rahim, R. (2019). Mathematical Issues in Data Science and Applications for Health care. International Journal of Recent Technology and Engineering, 8(2S11), 4153-4156. https://doi.org/10.35940/ijrte.B1599.0982 S1119

Tohir, M., Abidin, Z., Dafik, D., \& Hobri, H. (2018). Students Creative Thinking Skills in Solving Two Dimensional Arithmetic Series Through Research-Based Learning. Journal of Physics: Conference Series. https://doi.org/10.1088/17426596/1008/1/012072

Tohir, Mohammad, Susanto, Hobri, Suharto, \& Dafik. (2018). Students' Creative Thinking Skills in Solving Mathematics Olympiad Problems Based on ProblemSolving Polya and Krulik-Rudnick Model. Advanced Science Letters, 24(11), 
8361-8364.

https://doi.org/10.1166/asl.2018.12563

Usman, H. (2017). Pengembangan Instrumen Tes untuk Mengukur Kemampuan Penalaran Matematis Siswa MTsN 1 Model Kota Makassar. Universitas Islam Negeri Alauddin Makassar.

Yudha, F., Dafik, D., \& Yuliati, N. (2018). The Analysis of Creative and Innovative Thinking Skills of the 21st Century Students in Solving the Problems of "Locating Dominating Set" in Research Based Learning. International Journal of Advanced Engineering Research and Science, 5(3).

Zubaidah, S. (2018). Mengenal 4C: Learning and Innovation Skills untuk Menghadapi Era Revolusi Industri 4.0. Seminar "2nd
Science Education National Conference". Madura: Universitas Trunojoyo Madura.

\section{PROFIL SINGKAT}

Mohammad Mukhlis lahir di Lumajang 1991 merupakan dosen tadris matematika di salah satu perguruan tinggi ternama di Jember yaitu Institut Agama Islam Negeri Jember sejak bulan Juli 2019. Gelar sarjana di raih dari IKIP PGRI Jember pada 2013 dan menlanjutkan jenjang pendidikan magister di Universitas Jember pada tahun 2016 dan lulus pada tahun 2018. Mulai aktif menulis pada saat masuk saat menempuh gelar magister hingga tergabung pada kelompok riset CGANT (Combinatorics, Graph Theory, and Network Topology) dan masih aktif saat ini. 